\title{
REVIEW
}

\section{Cytoskeleton actin-binding proteins in clinical behavior of pituitary tumors}

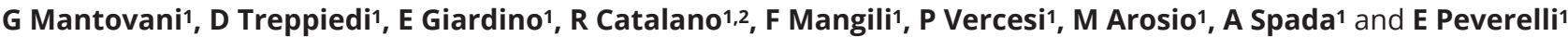 \\ 'Endocrinology Unit, Fondazione IRCCS Ca' Granda Ospedale Maggiore Policlinico, Department of Clinical Sciences and Community Health, \\ University of Milan, Milan, Italy \\ 2PhD Program in Endocrinological Sciences, Sapienza University of Rome, Rome, Italy
}

Correspondence should be addressed to G Mantovani: giovanna.mantovani@unimi.it

\begin{abstract}
Although generally benign, pituitary tumors are frequently locally invasive, with reduced success of neurosurgery and unresponsive to pharmacological treatment with somatostatin or dopamine analogues. The molecular basis of the different biological behavior of pituitary tumors are still poorly identified, but a body of work now suggests that the activity of specific cytoskeleton proteins is a key factor regulating both the invasiveness and drug resistance of these tumors. This review recapitulates the experimental evidence supporting a role for the actin-binding protein filamin A (FLNA) in the regulation of somatostatin and dopamine receptors expression and signaling in pituitary tumors, thus in determining the responsiveness to currently used drugs, somatostatin analogues and dopamine receptor type 2 agonists. Regarding the regulation of invasive behavior of pituitary tumoral cells, we bring evidence to the role of the actinsevering protein cofilin, whose activation status may be modulated by dopaminergic and somatostatinergic drugs, through FLNA involvement. Molecular mechanisms involved in the regulation of FLNA expression and function in pituitary tumors will also be discussed.
\end{abstract}

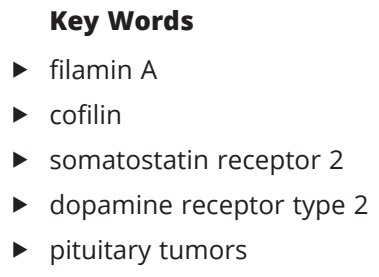

Endocrine-Related Cancer (2019) 26, R95-R108

\section{Introduction}

Pituitary tumors, accounting for $16.2 \%$ of all primary brain and other central nervous system tumors (Ostrom et al. 2017), are classified based on their secretory activity in non-functioning pituitary tumors (NFPTs) or hormone-secreting tumors, including prolactin (PRL)-, growth hormone (GH)- and adenocorticotropic hormone (ACTH)-secreting tumors. The 4 th edition of the World Health Organization (WHO) classification of endocrine tumors (Lloyd et al. 2017) has adopted an adenohypophyseal cell lineage designation, with subsequent categorization of histological variants according to hormone content and the expression of pituitary-specific transcription factors.
Therapy is aimed to remove or reduce tumor mass and to normalize hormone secretion. Transsphenoidal surgery is the first choice of treatment in many cases. However, incomplete tumor resection and high rate of recurrence are associated with pituitary tumors invasion into surrounding tissues, a feature found in $30-50 \%$ of the lesions (Meiji et al. 2002). For PRL-secreting tumors, dopamine receptor type 2 (DRD2) agonists represent the first-line therapy, whereas somatostatin analogs (SSAs) are used for the pharmacological treatment of GH- and ACTH-secreting tumors. However, a variable percentage of patients (about $10 \%$ of PRL-, 30\% of GH-, $50-70 \%$ of ACTH-secreting tumors) is resistant to these drugs 
(Colao et al. 2011, Cuevas-Ramos \& Fleseriu 2014, Guelho \& Grossman 2015, Tirosh \& Shimon 2015).

Little is known about the molecular determinants underlying the local invasiveness and the pharmacological resistance of pituitary tumors. However, cytoskeleton involvement in both these critical issues has been recently demonstrated by several studies.

\section{Cell cytoskeleton and pituitary tumors: old and new players}

Cell cytoskeleton is a complex, dynamic and multifunctional network of protein filaments that can be classified in three main types: microfilaments, intermediate filaments and microtubules, originating by polymerization of different protein subunits. Microfilaments are composed by actin, intermediate filaments mainly by vimentin and keratin and microtubules by tubulin. They are characterized by different structural and physical properties, enabling specific cellular functions. In addition to provide and maintain cell shape and structure, they participate in a variety of cellular processes. In particular, microfilaments are involved in cell movement, shape, differentiation, division and intracellular transport, these activities being regulated by specific interactions with a variety of actin-binding proteins. Intermediate filaments participate in cell-cell and cell-matrix junctions. Microtubules are involved in mitosis, organelles transport and cell shape. In addition, these three types of filaments interact both directly, by physical contact, and indirectly, via biochemical signaling and gene transcription, allowing reciprocal regulation.

A cytoskeleton involvement in secretory granules' transport and exocytosis in anterior pituitary cells has been demonstrated by electron microscopy techniques. Both actin filaments (Ostlund et al. 1977, Senda et al. 1989) and microtubules (Labrie et al. 1973, Sherline et al. 1977) bind anterior pituitary secretory granules in vitro, playing a role in their intracellular transport, approach to the plasma membrane and release. Moreover, agents that disrupt microtubules, such as colchicine or vinblastine, inhibited the transport of GH storage granules from the Golgi complex to the cytoplasmic pool (Howell \& Tyhurst 1978).

Specific cytoskeleton features have been associated to pituitary tumors clinical behavior. Cytokeratins, components of the intermediate filaments, that are expressed in both normal and tumoral anterior pituitary (Halliday et al. 1990) are specific histological markers that designate different subtypes of GH-secreting pituitary tumors. In particular, densely granulated tumors are defined by perinuclear cytokeratin distribution, whereas sparsely granulated tumors are characterized by dotlike keratin immunoreactivity, commonly referred to as fibrous bodies. Histological subtype of the tumor correlates with the expression of SS receptor type 2 (SSTR2) and response to SSA (Brzana et al. 2013, Chinezu et al. 2014, Kiseljak-Vassiliades et al. 2015), but to date, the molecular mechanisms involved are unknown.

Regarding actin-binding proteins, a role in regulating migration and invasion of pituitary adenomas has been attributed to fascin, which organizes actin filaments in parallel bundles (Liu et al. 2016). The authors demonstrated that silencing of fascin in GH3 cells reduced cell invasion, with a mechanism involving NOTCH1/DLL pathway. They also found an association between fascin expression and invasion and increased risk of recurrence in NFPT and GH-secreting tumors.

In the last years, two major actin-binding proteins, filamin A (FLNA) and cofilin, emerged as important players in the regulation of the complex intracellular processes that dictate pituitary tumors drug responsiveness and invasiveness. They participate in actin filaments crosslinking and remodeling, respectively, and in mediating SS and DA receptors intracellular effects.

\section{FLNA: structure and function}

Filamins (FLNs) are high-molecular-weight homodimeric actin-binding proteins which cross-link actin cytoskeleton filaments. FLNs family includes three homologous proteins, FLNA, B and C, encoded by different genes located on chromosome $\mathrm{X}, 3$ and 7 , respectively (van der Flier \& Sonnenberg 2001). While FLNC is primarily expressed in cardiac, smooth and striated muscle, FLNA and $\mathrm{B}$ are both ubiquitously expressed, but FLNA is the most abundant isoform (Feng \& Walsh 2004).

A complete loss of FLNA expression in mice causes embryonic lethality, cardiac malformations and skeletal defects (Hart et al. 2006). In humans, FLNA mutations lead to a broad spectrum of clinical disorders, called filaminopathies, which can be classified in loss of function or gain of function. FLNA loss-of-function mutations, leading to reduced or absent FLNA expression, are embryonic lethal in males but are manifest in females as periventricular nodular heterotopia (PVNH), a localized neuronal migration disorder during late embryonic and early fetal development, Ehlers-Danlos syndrome-like collagenopathy, macrothrombocytopenia and X-linked cardiac valvular dystrophy (XCVD) (Fox et al. 1998, Sheen
C) 2019 Society for Endocrinology Published by Bioscientifica Ltd. Printed in Great Britain 
et al. 2005, Bernstein et al. 2011, Ieda et al. 2018). FLNA variants can also present with seizures, cardiovascular and pulmonary findings (Robertson 2005).

In contrast, gain-of-function mutations of FLNA cause various skeletal dysplasias and congenital malformations affecting brain, viscera and urogenital tract (otopalatodigital syndromes, frontometaphyseal dysplasia and MelnickNeedles syndrome) (Robertson et al. 2003, Robertson 2005), strongly suggesting a FLNA role in modulating signaling during organogenesis in multiple tissues.

The structure of a FLNA monomer is represented in Fig. 1. FLNA was originally discovered as an actincrosslinking protein (Hartwig \& Stossel 1975), a function derived from its ability to homodimerize in V-shaped flexible structures that cross-link perpendicular actin filaments, conferring membrane integrity and defending cells against mechanical stress. Moreover, the binding of FLNA with several transmembrane proteins, including channels and receptors, anchors actin cytoskeleton to the cell membrane. Besides these structural functions, mounting evidence suggests a major role of FLNA in signal transduction, due to its ability to bind a huge number of intracellular signaling molecules, kinases and transcription factors (Stossel et al. 2001, Nakamura et al. 2011). FLNA is implicated in the regulation and integration of multiple cellular processes, including cell adhesion, migration,

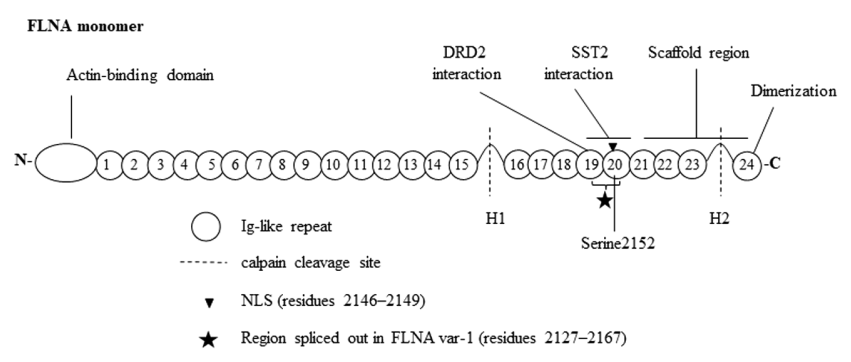

\section{Figure 1}

Schematic representation of a FLNA. A FLNA monomer is composed of 2647 amino acids and weights $280 \mathrm{kDa}$. At the $\mathrm{N}$-terminus there is an actin-binding domain that consists of two calponin homology domains, followed by 24 immunoglobulin (Ig)-like $\beta$-sandwich fold repeats of about 96 aminoacidic residues each. Repeats 1-15 (rod-1 domain) and 16-23 (rod-2 domain) are separated by a flexible hinge region $(\mathrm{H} 1)$, and another hinge $(\mathrm{H} 2)$ separates repeats 23 and 24 . FLNA can be cleaved by calpain at both $\mathrm{H} 1$ and $\mathrm{H} 2$. Repeat 24 is the self-association domain that mediates FLNA homodimerization. A secondary actin-binding domain of lower affinity is located in the rod-1 domain, whereas rod-2 does not interact with actin filaments, remaining free for interactions with multiple partner proteins. Indeed, the majority of FLNA interactions with receptors and signaling proteins are mediated by repeats 16-24. Repeats interacting with DRD2 and SST2, as well as FLNA scaffold region, are shown. Repeat 20 contains a putative nuclear localization signal (NLS) and the residue serine 2152 target of PKA phosphorylation. The deletion of 41 amino acids between repeat 19 and 20, present in the splice variant var-1 of FLNA, is indicated. maintenance of cell shape, differentiation, proliferation and transcription. Moreover, in different human tumors, FLNA may play opposite roles in regulating growth, invasion and metastasis (Shao et al. 2016).

FLNA functions are tightly regulated by several mechanisms, including FLNA phosphorylation, mechanical force, intramolecular inhibition, competition with other molecules and proteolysis, as discussed in 'Mechanisms regulating FLNA expression and function in pituitary tumors' section.

\section{Cofilin: structure and function}

The ADF/cofilin family is a key regulator of actin dynamics. It includes cofilin 1 (a non-muscle type of cofilin), cofilin 2 (a muscle type of cofilin) and ADF (actin-depolymerizing factor or destrin). Cofilin 1 (hereafter referred to as cofilin) is the most abundant and ubiquitous member of this family. Deletion of the cofilin gene CFL1 is embryonic lethal in mice owing to defects in proliferation, polarization and migration of neural crest cells (Gurniak et al. 2005, Bellenchi et al. 2007).

Cofilin is a small protein of $19 \mathrm{kDa}$ composed of one actin-depolymerizing factor homology (ADF-H) domain and able to bind both globular (G) actin and filamentous (F) actin. It also contains a NLS that confers to cofilin the ability to carry G-actin to nucleus (Abe et al. 1993, Pendleton et al. 2003), where it regulates chromosome organization and gene activity (Percipalle 2013).

Cofilin exerts two main biochemical functions: first, it depolymerizes ADP-bound actin filaments near the pointed ends to supply a pool of free G-actin monomers for polymerization; second, it severs actin filaments and initiates actin polymerization by increasing the number of actin-free barbed ends, from which F-actin polymerizes (Bravo-Cordero et al. 2013).

Since actin cytoskeleton reorganization is crucial for a number of cellular processes, it is not surprising that cofilin activity is tightly regulated. The main mechanism regulating cofilin activity is phosphorylation at Ser3 (Agnew et al. 1995), that prevents its ability to bind actin. Small GTPases of the Rho family are able to promote this posttranslational modification, by triggering a cascade of kinases, including PAK and ROCK, that activate LIMK1 and LIMK2, which ultimately target cofilin. On the other hand, cofilin is dephosphorylated by different phosphatases, such as slingshot $1 \mathrm{~L}$, chronophin and phosphatases type 1, 2A and 2B. Even though phosphorylated cofilin (P-cofilin) is generally considered the inactive form of cofilin, it can exert specific functions, such as to promote 
the translocation of phospholipase D1 to the plasma membrane and to stimulate its activity (Han et al. 2007). Beside phosphorylation, that remains the most important and the most studied system of cofilin regulation, other mechanisms have been described, such as cofilin ubiquitination, $\mathrm{pH}$ alterations, oxidation, binding to PtdIns $(4,5) \mathrm{P}_{2}$ or to tropomyosins, cortactin, CAP1/Srv2p, coronins and Aip1 (Bernstein \& Bamburg 2010), that might contribute to finely tune cofilin activity.

Cofilin has been demonstrated to be involved in cancer development, progression, invasion and metastasis. Both an increase of cofilin expression and a reduction of cofilin phosphorylation has been found in human malignant cells, suggesting its potential use as diagnostic/prognostic tumor biomarker (reviewed in Shishkin et al. 2016).

\section{Cytoskeleton role in pituitary tumors drug responsiveness}

\section{FLNA role in PRL-secreting tumors responsiveness to DRD2 agonists}

FLNA involvement in DRD2 regulation is well established. FLNA repeat 19 directly binds DRD2 third intracellular loop (Lin et al. 2001), with a strong impact on DRD2 coupling to adenylate cyclase, receptor clustering and expression on the plasma membrane in human melanoma cells (Li et al. 2000, Lin et al. 2002) (Fig. 1).

Concerning PRL-secreting pituitary tumors, Peverelli et al. showed that the presence of FLNA is essential for DRD2 expression and intracellular transduction of dopamine inhibitory signals (Peverelli et al. 2012). The authors demonstrated that tumor tissues from patients resistant to DRD2 agonists treatment showed a reduced expression of both DRD2 and FLNA, by both immunohistochemistry and Western blot. Moreover, they showed by in vitro experiments that the absence of FLNA caused the loss of DRD2. Indeed, FLNA gene silencing or overexpression in primary cultured prolactinoma cells from drug-sensitive or -resistant tumors produced corresponding decrease or increase, respectively, of DRD2 (Peverelli et al. 2012). The molecular mechanism involved has been elucidated in MMQ, a rat cell model of prolactinoma endogenously expressing functional DRD2 and FLNA. In these cells, FLNA was required for both DRD2 targeting to the cell membrane and DRD2 protection against lysosomal degradation (Peverelli et al. 2012) (Fig. 2). In agreement

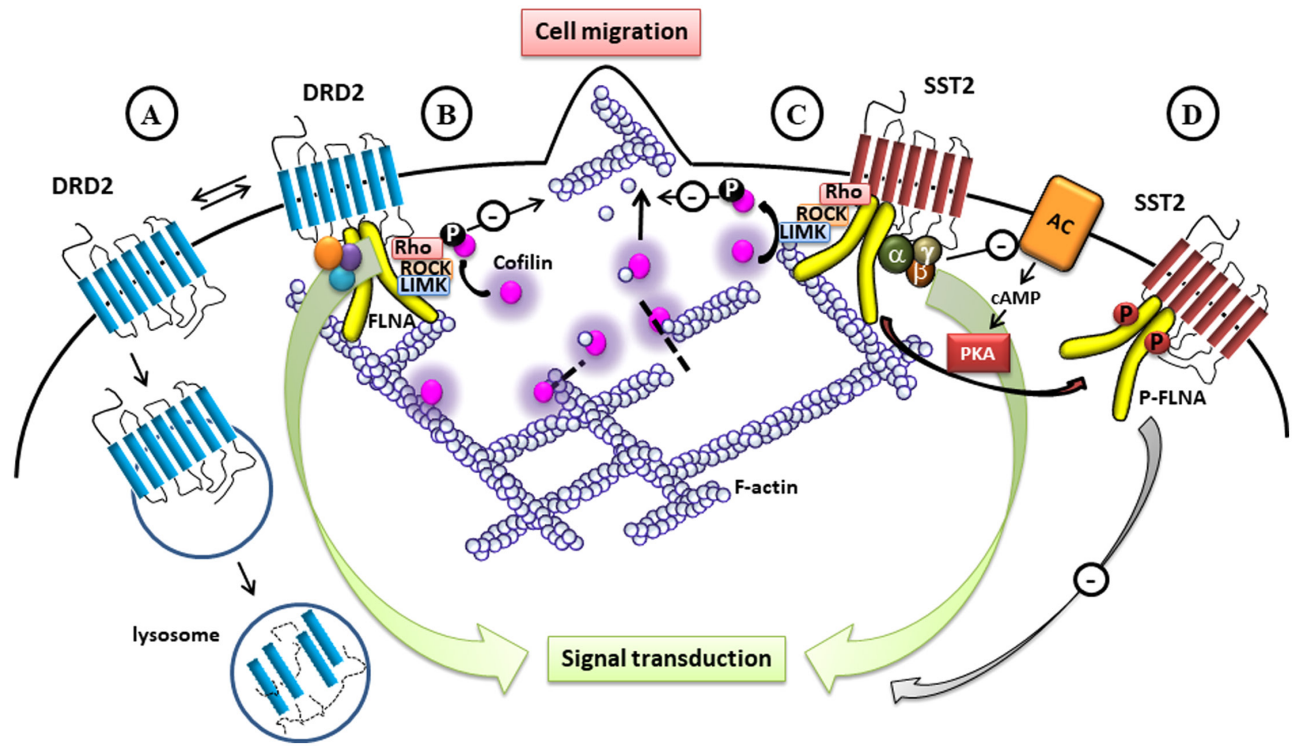

Figure 2

The figure schematically represents the proposed model of cytoskeleton involvement in regulating DRD2 and SST2 in pituitary tumor cells, and the interplay between FLNA, cofilin and receptors in regulating tumor cell motility. (A) FLNA stabilizes DRD2 expression by preventing its lysosomal degradation, and functions as scaffold in mediating DRD2 signal transduction. (B) DRD2 activates ROCK/LIMK/cofilin pathway, promoting an increase of cofilin phosphorylation (inactivation), with consequent reduction of cell migration and invasion. (C) FLNA interaction with SST2 is required for SST2 clusters formation and alignment along actin fibers, prevents SST2 lysosomal degradation upon agonist challenge and functions as scaffold for inhibitory G proteins allowing SST2 signal transduction. Activated SST2 recruits a protein complex that includes FLNA, RhoA, ROCK, LIMK and cofilin, promoting cofilin phosphorylation and a consequent inhibition of cell migration. (D) FLNA phosphorylation regulates SST2 signal transduction. CAMP/PKA pathway activation induces FLNA phosphorylation. P-FLNA constitutively binds SST2, and hampers its coupling with inhibitory G proteins after agonist activation. SST2, when bound to dephosphorylated FLNA, inhibits adenylyl cyclase activity, with a consequent reduction of PKA-mediated FLNA phosphorylation. 
with a role for FLNA in the control of DRD2 fate after endocytosis, it has been shown in HEK293 cells that FLNA regulates DRD2 internalization and recycling (Zheng et al. 2016).

These data support the notion that FLNA is a trafficking adaptor, which allows an efficient recycling of GPCRs, as also showed for chemokine receptor CCR2 and $\beta 2$-adrenergic receptor (Pons et al. 2017), and a protection against degradation, as demonstrated for calciumsensing receptor (Zhang \& Breitwieser 2005), calcitonin receptor (Seck et al. 2003), cystic fibrosis transmembrane conductance regulator (Thelin et al. 2007) and FcgammaRI (Beekman et al. 2008).

However, the role of FLNA in DRD2 regulation is not limited to guarantee the appropriate levels of the receptor on the plasma membrane, but extends to a scaffold function that enable DRD2 signal transduction. The work of Peverelli et al. demonstrated that in primary cultured human PRL-secreting cells, FLNA silencing prevented the inhibitory effects of DRD2 on PRL secretion and ERK1/2 phosphorylation (Peverelli et al. 2012). On the other hand, DA-resistant prolactinoma cells transfected with FLNA become able to respond to dopaminergic drugs (Peverelli et al. 2012).

Due to this function of FLNA in DRD2 expression and signaling in lactotrophs, the loss of FLNA expression may be one of the mechanisms involved in resistance of prolactinomas to dopaminergic drugs. Overall, these data reveal FLNA as a novel potential target to modulate the amount of active DRD2 at the cell membrane in PRL-secreting pituitary tumor cells (Fig. 2).

\section{FLNA role in GH-secreting tumor responsiveness to SSAs}

In GH-secreting tumors, SSTR2 is the main target of pharmacological therapy. A positive correlation of SSTR2 expression with tumor response to medical therapy with SSA is well documented in literature, but resistance to SSAs has been observed also in the presence of SSTR2, suggesting post-receptor mechanisms involved (revised in Peverelli et al. 2015, Gadelha et al. 2017, Paragliola et al. 2017, Marazuela et al. 2018). The efficacy of SSA can be reduced due to an altered expression of beta arrestins, scaffold proteins involved both in desensitization and signal transduction of several GPCRs, including SSTRs (Tulipano et al. 2004, Peverelli et al. 2008). Indeed, low expression of beta arrestin 1 , but not beta arrestin 2 , correlated with a reduced recycling rate of SSTR2 and a better biochemical response to SSA, both in vitro and in vivo (Gatto et al.
2013). Alterations in SSTRs signal transduction might be due to aryl hydrocarbon receptor-interacting protein (AIP) tumor-suppressor gene mutations (Daly et al. 2010), typically correlating with octreotide resistance (IbáñezCosta \& Korbonits 2017). Moreover, tumor resistance has been associated with alterations of the expression of Raf kinase inhibitory protein, which regulates MAPK signaling, a pathway involved in mediating the antiproliferative effects of somatostatin (Fougner et al. 2008).

Recently, a role for FLNA in both SSTR2 expression after prolonged agonist stimulation and signal transduction has been described. FLNA can directly bind SSTR2 first intracellular loop by its repeats 19-20 (Najib et al. 2012) (Fig. 1). In GH-secreting tumors tissues, FLNA protein is expressed at variable levels, with no correlation with SSTR2 expression (Peverelli et al. 2014), in striking contrast with DRD2 in prolactinomas (Peverelli et al. 2012). In addition, FLNA is not required for a proper localization of SSTR2 on the plasma membrane. Indeed, FLNA silencing in primary cultures of somatotropinomas does not affect SSTR2 intracellular localization on the plasma membrane neither its expression levels (Peverelli et al. 2014), in agreement with the evidence that in melanoma cell lines SSTR2 membrane localization does not depend on the presence of FLNA (Najib et al. 2012).

At higher level of detail, single-molecule microscopy analysis recently showed that dynamic SSTR2-FLNA interactions control SSTR2 spatial arrangement and mobility at the plasma membrane and are required for the formation of SSTR2 clusters and their alignment along actin fibers in CHO cells (Treppiedi et al. 2018). In addition, the transfection of a dominant negative FLNA fragment (FLNA 19-20), which prevents FLNA-SSTR2 binding (Peverelli et al. 2014), impaired the coupling of SSTR2 clusters to clathrin-coated pits, with a consequent decrease of SSTR2 internalization (Treppiedi et al. 2018) (Fig. 3).

A role for FLNA in dictating the fate of agonistactivated SSTR2, in analogy with DRD2, is supported by the observation that in GH-secreting pituitary tumor cells SSTR2-FLNA interaction is required to prevent activated SSTR2 lysosomal degradation and to maintain SSTR2 stability after prolonged agonist stimulation (Peverelli et al. 2014).

At the same time, FLNA is required for SSTR2 signal transduction. In human GH-secreting tumor primary cultured cells, FLNA silencing prevented SSTR2-induced reduction of cyclin D1 and activation of caspase 3/7, required for the antiproliferative and pro-apoptotic effects of SSTR2 (Peverelli et al. 2014). The FLNA 

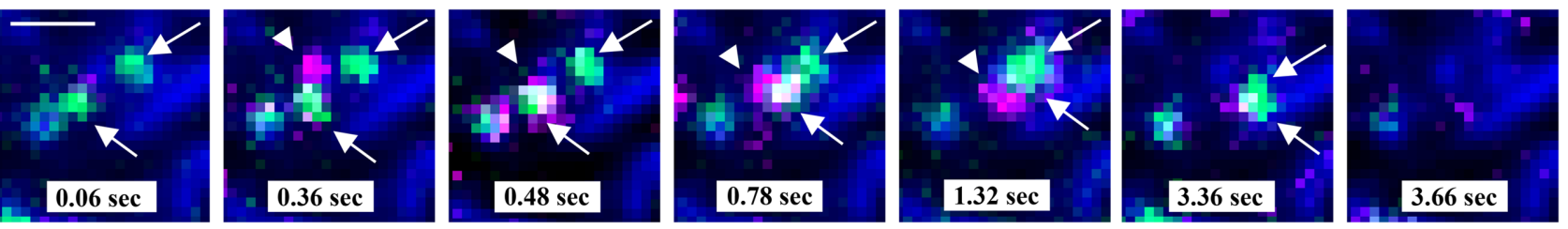

\section{Figure 3}

Selected frames from a representative image sequence acquired with a total internal reflection fluorescence (TIRF) microscope showing a portion of the cell surface of a CHO cell co-expressing single molecules of SSTR2 (green) and FLNA (magenta) and actin filaments (blue). TIRF microscopy is a powerful tool to visualize cell plasma membrane associated events, such as lateral movements of receptor and protein-protein interactions. Thanks to the higher signal-to-noise ratio compared to epifluorescence, tracking algorithms can be applied to link detected particles in each frame of the acquired image sequence and reconstruct particles trajectories. This example shows the dynamics of a typical FLNA-SSTR2 interaction and the involvement of FLNA in SSTR2 clusters formation and internalization after SSTR2 stimulation with a specific agonist. Two cell surface SSTR2 molecules are indicated by arrows at the beginning of the image sequence $(0.06 \mathrm{~s})$. A FLNA molecule, indicated by the arrowhead, appears at the cell surface $(0.36 \mathrm{~s})$ and subsequently co-localizes with the SSTR2 particle at the bottom $(0.48 \mathrm{~s})$. The FLNA-SSTR2 complex gets in close proximity to the other SSTR2 particle $(0.78 \mathrm{~s})$ and a receptor cluster is then formed (1.32 s and $3.36 \mathrm{~s})$. SSTR2 cluster disappears from cell surface ( $3.66 \mathrm{~s})$, due to its internalization. Scale bar, $1 \mu \mathrm{m}$.

scaffold domain involving repeats $21-24$ seems to play a paramount role in facilitating SSTR2 signaling. Indeed, overexpression of dominant negative mutant FLNA 21-24, that does not abolish the interaction of SSTR2 with endogenous FLNA, eliminated SSTR2 effects on apoptosis and ERK1/2 inhibition. These data suggest that the FLNA scaffold properties are required for the recruitment of signal transduction complexes to activated SSTR2. Another mechanism by which FLNA mediates SSTR2 antiproliferative action has been demonstrated in pancreatic neuroendocrine tumors, where a competition of FLNA with PI3K regulatory subunit p85 for the binding to SSTR2 occurs (Najib et al. 2012), and where FLNA is required for SSTR2 expression and signaling (Vitali et al. 2016). FLNA is also required to mediate the inhibitory effects of SSTR2 on cell migration and invasion in GH-secreting pituitary tumors (Peverelli et al. 2018a), by mediating the recruitment to activated SSTR 2 of components of the cofilin pathway, as discussed below.

Altogether, these data support the idea that FLNA functions as a molecular platform able to connect SSTR2 with components of the machinery of intracellular trafficking and of the signal transduction cascade (Fig. 2).

Thus, low levels of FLNA in GH-secreting pituitary tumors, by causing loss of coupling of SSTR2 with downstream signal transduction molecules, might cause loss of responsivity of the patient to SS analogs even if in the presence of appropriate levels of SSTR2. Further studies in a large series of patients are required to investigate a possible correlation between FLNA expression levels and clinical behavior of GH-secreting tumors.

Despite the amino acidic sequence of SSTR2 required for FLNA binding is conserved in SSTR5, no data are found in literature about a FLNA role in regulating SSTR5.
This receptor subtype is highly expressed in GH-secreting tumors and is the most expressed SSTRs in ACTH-secreting tumors. Since the multi-ligand SSA pasireotide represents the only pituitary-directed drug approved by regulatory authorities to treat Cushing's disease, at least in Europe, it would be of great interest to evaluate a possible FLNA role in molecular mechanisms underlying the resistance to pasireotide, occurring in $50-70 \%$ of patients with Cushing's disease (Guelho \& Grossman 2015).

\section{Cytoskeleton role in pituitary tumors invasiveness}

\section{Cofilin promotes NFPT invasiveness and is regulated by DRD2}

Non-functioning pituitary tumors (NFPTs) frequently show local invasiveness that strongly reduces the success of transsphenoidal neurosurgery, the treatment of choice for this type of tumor, and increases the incidence of tumor recurrence (Meiji et al. 2002, Losa et al. 2008). No diagnostic molecular markers predictive of the invasive behavior and recurrence of NFPTs are available. Moreover, the molecular mechanisms underlying the invasive behavior of these mostly benign tumors are unknown.

Overexpression of cofilin has been associated with tumor cell proliferation, invasion and metastasis in astrocytoma (Nagai et al. 2011), breast (Wang et al. 2006, Zhang \& Tong 2010), colon (Popow-Woźniak et al. 2012), pancreatic (Wang et al. 2015), prostate (Collazo et al. 2014) and gallbladder (Yang et al. 2013) tumors, and cofilin dephosphorylation was observed in human malignant cells (Nagai et al. 2011). https://erc.bioscientifica.com https://doi.org/10.1530/ERC-18-0442 (c) 2019 Society for Endocrinology Published by Bioscientifica Ltd. Printed in Great Britain 
A role for cofilin in promoting invasion of NFPTs has recently been demonstrated. Peverelli et al. showed that overexpression of cofilin induced an increase of cell migration of human non-functioning pituitary tumor HP75 cells, an effect reproduced by the constitutively active cofilin phosphodeficient mutant S3A, but not phosphomimetic S3D (Peverelli et al. 2016). Moreover, the pro-migratory effect of active S3A cofilin was supported by its intracellular co-localization with F-actin in membrane protrusions in HP75 cells, in contrast to S3D cofilin, which is diffusely distributed in the cytoplasm.

These in vitro data are well supported by the analysis of cofilin phosphorylation in human NFPT tissues. Indeed, Western blot analysis demonstrated higher phosphorylated cofilin (P-cofilin)/total cofilin ratio in non-invasive than in invasive NFPTs, and immunohistochemistry analysis showed a low or absent P-cofilin staining in invasive tumors, in contrast with high immunoreactivity for P-cofilin found in non-invasive tumors (Peverelli et al. 2016). From these experiments, cofilin emerges as a potential new biomarker predictive of NFPTs invasiveness and recurrence, which could provide additional information for prognosis influencing the management of patients and the use of adjuvant therapies.

DRD2 is expressed in most NFPTs (Vieira Neto et al. 2015) but medical therapy with DRD2 agonists is still under debate (Delgado-López et al. 2018). Beside antiproliferative activity (Colao et al. 2000, Florio et al. 2008, Peverelli et al. 2010, Gagliano et al. 2013), DRD2 was recently demonstrated able to exert anti-migratory and anti-invasive activity in cultured cells from NFPTs and HP75 cells (Peverelli et al. 2016). This unprecedented effect of DRD2 in a tumor cell model is a consequence of the DRD2 ability to modify the intracellular pool of P-cofilin. Indeed, in these cells, DRD2 agonist promoted a Rho-associated protein kinase ROCK-dependent LIMK phosphorylation, which in turn induced cofilin phosphorylation (Fig. 2). To date, DRD2 coupling with RhoA/ROCK signaling pathway has been described only in mouse striatal neurons (Deyts et al. 2009, GalanRodriguez et al. 2017), but the molecular mechanism involved has never been investigated. As described below, FLNA may function as scaffold linking together GPCRs and components of the cofilin pathway (Peverelli et al. 2018a), suggesting that DRD2 effect on P-cofilin may be mediated by FLNA. However, G proteins coupled to DRD2, or beta arrestins, involved in DRD2 internalization (Kim et al. 2001) and able to activate Rho (Barnes et al. 2005, Ma et al. 2012), may be potential molecular players connecting DRD2 to cofilin pathway.
These data first suggest a new role for DRD2 agonists in the control of invasive properties of NFPTs. Indeed, DRD2 actively participates in actin fibers remodeling by controlling cofilin activation, with important consequences on cell migration and invasion.

Despite DRD2 being the main target of PRL-secreting tumors therapy, no data about DRD2 agonists effects on invasion and cofilin phosphorylation in prolactinomas are available in literature. However, it was demonstrated that exposure of lactotrophs to dopamine stabilized the cortical actin cytoskeleton (Carbajal \& Vitale 1997), consistently with an increase of P-cofilin.

Finally, the recent observation that the coupling of DRD2 to RhoA/ROCK pathway is specific of the short spliced version of the receptor (D2S) (Galan-Rodriguez et al. 2017) deserves further considerations. This DRD2 isoform differs from the long one (D2L) for the loss of 29 amino acids in the third intracellular loop, resulting in different physiological functions. The differential expression of these two splice variants has been associated with the biological behavior of PRL-secreting tumors. Indeed, lower expression of D2S transcript correlated with resistance to dopaminergic drugs (Caccavelli et al. 1994, Wu et al. 2010) and tumor invasiveness (Wu et al. 2010), consistent with a reduced or absent coupling of D2L with cofilin pathway.

\section{GH-secreting tumors invasiveness is regulated by SSTR2 through FLNA-mediated cofilin inactivation}

Invasion of the cavernous sinus, reported in $20-50 \%$ of patients with GH-secreting tumors, represents a clinical issue since the outcomes of transsphenoidal surgery are less favorable for the lesions invading surrounding tissues (Sarkar et al. 2014, Anik et al. 2017).

Recently, an anti-migratory effect of SSTR2 in $\mathrm{GH}$-secreting tumor cells has been discovered, in addition to its recognized antiproliferative and pro-apoptotic actions (Peverelli et al. 2018a). This previously unknown SSTR2 ability to actively participate to cytoskeleton remodeling is mediated by FLNA and cofilin.

The specific SSTR2 agonist BIM23120 inhibited migration and invasion on collagen IV in both primary cultured cells from human GH-secreting tumors and GH3 cell line (Peverelli et al. 2018a). It is of clinical relevance noting that these effects are reproduced by the two SSAs used in the pharmacological therapy of pituitary tumors: octreotide, with high preferential binding affinity for SSTR2, and pasireotide, with a broader spectrum of affinity for different receptor subtypes and high binding affinity to SST5. 
The investigation about the molecular machinery involved identified the RhoA/ROCK/cofilin pathway as a new intracellular signaling cascade activated by SSTR2 (Peverelli et al. 2018a). Indeed, in GH3 cells, selective SSTR 2 activation by BIM23120 strongly activated RhoA and induced a ROCK-mediated increase of P-cofilin/total cofilin ratio, which was required for the anti-invasive effects of SSTR2, in analogy with the mechanisms employed by DRD2 to reach the same effect in NFPT cells (Fig. 2).

In addition, the phosphorylation status of cofilin appeared to be an important regulator of GH-secreting tumor cells motility, since transfection of constitutively inactive phosphomimetic S3D cofilin was able to reduce GH3 cell invasion independently from SSTR2 activation, whereas no effect was observed after transfection of S3A or WT cofilin.

Thus, S3D cofilin functions in a dominant negative manner in this type of tumor, in line with the observation that it may compete with endogenous phosphorylated cofilin for binding to specific phosphatases, with a consequent increase of cofilin phosphorylation status (Chua et al. 2003).

The effects of overexpression of active S3A cofilin depend on the cell line. Indeed, S3A cofilin increased NFPT, but not GH-secreting, cell invasion (Peverelli et al. 2016, 2018a), supporting the hypothesis that multiple, cell-specific mechanisms, other than phosphorylation, are required to control the initial activation of cofilin (Song et al. 2006).

In line with the function of FLNA as scaffold for SSTR2 signal transduction molecules (Peverelli et al. 2014), the activation of cofilin pathway required FLNA, as demonstrated by both FLNA genetic silencing and transfection of FLNA dominant negative mutants preventing FLNA binding to SSTR2 (FLNA 19-20) or to signaling molecules (FLNA 21-24) (Peverelli et al. 2018a). Moreover, by confocal microscopy and coimmunoprecipitation assays, the authors demonstrated that upon agonist challenge SSTR2 colocalized with FLNA and cofilin at the plasma membrane, but cofilin recruitment to SSTR2 was completely lost in cells silenced for FLNA.

These data suggest that activated SSTR2 recruits a macromolecular complex that through FLNA anchors SSTR2 to actin fibers and connects molecular components of the cofilin pathway, enabling a direct effect of SSTR2 on actin cytoskeleton dynamics (Fig. 2).

Intriguingly, the overexpression of FLNA19-20 and 21-24 in GH3 cells reduced cell invasion, independently from SSTR2 selective stimulation, first revealing a role of these peptides as inhibitors of tumor cell invasiveness (Peverelli et al. 2018a).

The molecular mechanism involved might be related to the ability of FLNA to bind molecules that participate in the regulation of cell adhesion and migration processes. Indeed, the FLNA regions contained in both these dominant negative mutants are required for cell spreading and initiation of cell migration (Baldassarre et al. 2009) and integrin binding (Kiema et al. 2006, Ithychanda et al. 2009).

\section{Mechanisms regulating FLNA expression and function in pituitary tumors}

\section{FLNA expression}

The molecular events responsible for a low or absent FLNA expression in pituitary tumors remain an open question. A possible role for epigenetic silencing has been ruled out, at least in PRL-secreting tumors, since no methylation in the FLNA promoter regions was found neither in FLNA expressing nor in non-expressing prolactinomas (Peverelli et al. 2012).

Despite several germline FLNA mutations that lead to reduced or absent FLNA expression have been identified in human disease (see below), a possible presence of FLNA somatic mutations in pituitary tumors has never been investigated.

FLNA degradation is promoted by ubiquitination triggered by ASB2 proteins, subunits of E3 ubiquitin ligase complexes (Razinia et al. 2011). No data about FLNA ubiquitination and degradation process in pituitary tumors are available, but it is of interest to note that alterations of ubiquitin system due to somatic mutations of ubiquitin-specific peptidase 8 (USP8) gene play a pathogenetic role in the development of ACTH-secreting pituitary tumors (Reincke et al. 2015).

\section{FLNA splicing variants}

It is known that FLNA mRNA is subjected to alternative splicing. Among the described splice variants, of interest is the FLNA splice variant-1 (var-1), containing an internal deletion of 41 amino acids between C-terminal part of repeat 19 and the N-terminal part of repeat 20 (residues 2127-2167) (Pentikäinen et al. 2011) (Fig. 1). This deletion increased FLNA/integrins binding compared with nonspliced FLNA (van der Flier et al. 2002), suggesting a general role for this alternative splicing in regulating 
FLNA binding to its interaction partners. Since FLNA regions that directly interact with SSTR2 and DRD2 are located in repeats 19-20, an altered binding of FLNA var-1 to these receptors can be hypothesized. Moreover, it is worth noting that the aminoacidic residues spliced out in FLNA var-1 include serine 2152, target of phosphorylation (see below), and the putative NLS (2146-2149), with possible important implications for FLNA functions.

FLNA var-1 is widely expressed at low levels, but up to now no data about the expression of this variant in normal and tumoral pituitary is known. It is possible to hypothesize that the alternative splicing of FLNA may have implications in pituitary tumors responsiveness to SSAs and DRD2 agonists.

Mutations in FLNs splice sites have been previously associated with human diseases, such as PVNH (Oegema et al. 2013) and dilated cardiomyopathy (Begay et al. 2016), involving FLNA and FLNC, respectively.

\section{FLNA phosphorylation}

FLNA is target of phosphorylation of different kinases, such as PKA, PKC, CaM-kinase II, Pak1 (p21-activated kinase 1), RSK (ribosomal S6 kinase) and cyclin B1/Cdk1 (Chen \& Stracher 1989, Jay et al. 2004, Woo et al. 2004, Cukier et al. 2007, Zhang et al. 2012, Hammer et al. 2013).

This posttranslational modification critically modulates FLNA functions, since it has been implicated in cell migration (Woo et al. 2004, Ravid et al. 2008, Zhang et al. 2012, Hammer et al. 2013, Li et al. 2015, Sato et al. 2016) focal adhesion formation (Sato et al. 2016), integrin binding (Chen et al. 2009, Sato et al. 2016), calpainmediated FLNA proteolysis (Zhang et al. 1988, Chen \& Stracher 1989, Wu et al. 1994, Jay \& Stracher 1997, García et al. 2006, Bedolla et al. 2009) and chemokine receptor 2 recycling (Pons et al. 2017).

The N-terminal region of FLNA contains a PKA site probably involved in F-actin interaction (Jay \& Stracher 1994), whereas the only PKA phosphorylation site in the C-terminal region of FLNA is serine 2152 in the repeat 20 of FLNA (Jay et al. 2000) (Fig. 1). cAMP/PKA pathway activation induced FLNA phosphorylation at S2152 in different cell systems (Chen \& Stracher 1989, Jay et al. 2000, 2004), and recently, the same effect has been reported in GH-secreting pituitary tumors.

Indeed, in both GH3 and GH4C1 cell lines and in primary cultured cells from GH-secreting pituitary tumors, forskolin increased, and SSTR2 agonist reduced, FLNA phosphorylation at S2152, with dramatic effects on FLNA binding to SSTR2 and SSTR2 signal transduction
(Peverelli et al. 2018b) (Fig. 2). The authors demonstrated that the phosphomimetic S2152D FLNA mutant constitutively bound to SSTR2, but precluded inhibitory G proteins coupling to SSTR2, and completely abolished antiproliferative, pro-apoptotic and anti-migratory effects of selective SSTR2 activation by BIM23120 (Fig. 2) (Peverelli et al. 2018b). In this scenario, phosphorylation seems to be a mechanism to switch FLNA function from a scaffold that allows SSTR2 signal transduction, to a signal termination protein that hampers all SSTR2 antitumoral effects (Fig. 2).

In a broader perspective, further studies are needed to investigate whether this mechanism may control the activity of other GPCRs that bind FLNA. In the field of pituitary tumors, the study of the FLNA phosphorylation offers new insights into the molecular determinants underlying SSA resistance of pituitary tumors and suggests phosphorylated FLNA as a novel biomarker predicting GH-secreting tumor responsiveness to SSA.

\section{Conclusions}

Cell cytoskeleton proteins, clearly far from being only structural cell components, are critically involved in the complex molecular machinery that determines the biological behavior of pituitary tumors. In particular, the multifunctional protein FLNA appears to be a molecular platform that by facilitating the interplay with several partners orchestrates DRD2 and SSTR2 expression, localization, internalization, intracellular trafficking, signal transduction and signal termination.

Therefore, its proper function is a mandatory requirement for the antitumoral action of dopaminergic and somatostatinergic drugs in pituitary tumors.

The biological responses to these currently used drugs do not only include the well-established inhibitory effects on hormone secretion and tumor growth, but also include the ability to restraint tumoral cell migration and invasion. It is not surprising that FLNA acts as an intermediary between the receptors of these drugs on the cell surface and the actin filaments of the cell cytoskeleton, also allowing the recruitment of the components of the pathway of cofilin, a protein specifically involved in actin filaments remodeling.

In this scenario, further studies aimed to deeply investigate the mechanisms of regulation of FLNA and cofilin might suggest new pharmacological strategies for DA or SSA resistant and invasive pituitary tumors. One important direction for future studies is to determine a possible crosstalk between the different cytoskeletal (c) 2019 Society for Endocrinology Published by Bioscientifica Ltd. Printed in Great Britain 
components identified as crucial in pituitary biology, including FLNA, actin, cofilin, keratins and E-cadherin.

Understanding the molecular basis underlying the different biological behaviors of pituitary tumors will be a key milestone in reaching a personalized approach to treatment of this disease.

\section{Declaration of interest}

The authors declare that there is no conflict of interest that could be perceived as prejudicing the impartiality of this review.

\section{Funding}

This study was supported by AIRC (Associazione Italiana Ricerca Cancro) grant to G M (IG 2017-20594), a Pfizer grant to E P (WI219094), Ricerca Corrente Funds from the Italian Ministry of Health and Progetti di Ricerca di Interesse Nazionale (PRIN) grant to G M (2015ZHKFTA).

\section{References}

Abe H, Nagaoka R \& Obinata T 1993 Cytoplasmic localization and nuclear transport of cofilin in cultured myotubes. Experimental Cell Research 206 1-10. (https://doi.org/10.1006/excr.1993.1113)

Agnew BJ, Minamide LS \& Bamburg JR 1995 Reactivation of phosphorylated actin depolymerizing factor and identification of the regulatory site. Journal of Biological Chemistry 270 17582-17587. (https://doi.org/10.1074/jbc.270.29.17582)

Anik I, Cabuk B, Gokbel A, Selek A, Cetinarslan B, Anik Y \& Ceylan S 2017 Endoscopic transsphenoidal approach for acromegaly: remission rates in 401 patients: 2010 consensus criteria. World Neurosurgery S1878-8750 31492-31494.

Baldassarre M, Razinia Z, Burande CF, Lamsoul I, Lutz PG \& Calderwood DA 2009 Filamins regulate cell spreading and initiation of cell migration. PLOS ONE $\mathbf{4}$ e7830. (https://doi.org/10.1371/ journal.pone.0007830)

Barnes WG, Reiter E, Violin JD, Ren XR, Milligan G \& Lefkowitz RJ 2005 beta-Arrestin 1 and Galphaq/11 coordinately activate RhoA and stress fiber formation following receptor stimulation. Journal of Biological Chemistry 280 8041-8050. (https://doi.org/10.1074/jbc.M412924200)

Bedolla RG, Wang Y, Asuncion A, Chamie K, Siddiqui S, Mudryj MM, Prihoda TJ, Siddiqui J, Chinnaiyan AM, Mehra R, et al. 2009 Nuclear versus cytoplasmic localization of filamin A in prostate cancer: immunohistochemical correlation with metastases. Clinical Cancer Research 15 788-796. (https://doi.org/10.1158/1078-0432.CCR-08-1402)

Beekman JM, van der Poel CE, van der Linden JA, van den Berg DL, van den Berghe PV, van de Winkel JG \& Leusen JH 2008 Filamin A stabilizes Fc gamma RI surface expression and prevents its lysosomal routing. Journal of Immunology 180 3938-3945. (https://doi. org/10.4049/jimmunol.180.6.3938)

Begay RL, Tharp CA, Martin A, Graw SL, Sinagra G, Miani D, Sweet ME, Slavov DB, Stafford N, Zeller MJ, et al. 2016 FLNC gene splice mutations cause dilated cardiomyopathy. JACC: Basic to Translational Science 1 344-359. (https://doi.org/10.1016/j.jacbts.2016.05.004)

Bellenchi GC, Gurniak CB, Perlas E, Middei S, Ammassari-Teule M \& Witke W $2007 \mathrm{~N}$-cofilin is associated with neuronal migration disorders and cell cycle control in the cerebral cortex. Genes and Development 21 2347-2357. (https://doi.org/10.1101/gad.434307)

Bernstein BW \& Bamburg JR 2010 ADF/cofilin: a functional node in cell biology. Trends in Cell Biology 20 187-195. (https://doi.org/10.1016/j. tcb.2010.01.001)
Bernstein JA, Bernstein D, Hehr U \& Hudgins L 2011 Familial cardiac valvulopathy due to filamin A mutation. American Journal of Medical Genetics Part A 155A 2236-2241. (https://doi.org/10.1002/ ajmg.a.34132)

Bravo-Cordero JJ, Magalhaes MA, Eddy RJ, Hodgson L \& Condeelis J 2013 Functions of cofilin in cell locomotion and invasion. Nature Reviews: Molecular Cell Biology 14 405-415. (https://doi.org/10.1038/ nrm3609)

Brzana J, Yedinak CG, Gultekin SH, Delashaw JB \& Fleseriu M 2013 Growth hormone granulation pattern and somatostatin receptor subtype $2 \mathrm{~A}$ correlate with postoperative somatostatin receptor ligand response in acromegaly: a large single center experience. Pituitary 16 490-498. (https://doi.org/10.1007/s11102-012-0445-1)

Caccavelli L, Feron F, Morange I, Rouer E, Benarous R, Dewailly D, Jaquet P, Kordon C \& Enjalbert A 1994 Decreased expression of the two D2 dopamine receptor isoforms in bromocriptine-resistant prolactinomas. Neuroendocrinology 60 314-322. (https://doi. org/10.1159/000126764)

Carbajal ME \& Vitale ML 1997 The cortical actin cytoskeleton of lactotropes as an intracellular target for the control of prolactin secretion. Endocrinology 138 5374-5384. (https://doi.org/10.1210/ endo.138.12.5565)

Chen M \& Stracher A 1989 In situ phosphorylation of platelet actinbinding protein by cAMP-dependent protein kinase stabilizes it against proteolysis by calpain. Journal of Biological Chemistry 264 14282-14289.

Chen HS, Kolahi KS \& Mofrad MR 2009 Phosphorylation facilitates the integrin binding of filamin under force. Biophysical Journal 97 3095-3104. (https://doi.org/10.1016/j.bpj.2009.08.059)

Chinezu L, Vasiljevic A, Jouanneau E, François P, Borda A, Trouillas J \& Raverot G 2014 Expression of somatostatin receptors, SSTR2A and SSTR5, in 108 endocrine pituitary tumors using immunohistochemical detection with new specific monoclonal antibodies. Human Pathology 45 71-77. (https://doi.org/10.1016/j. humpath.2013.08.007)

Chua BT, Volbracht C, Tan KO, Li R, Yu VC \& Li P 2003 Mitochondrial translocation of cofilin is an early step in apoptosis induction. Nature Cell Biology 5 1083-1089. (https://doi.org/10.1038/ncb1070)

Colao A, Ferone D, Lastoria S, Cerbone G, Di Sarno A, Di Somma C, Lucci R \& Lombardi G 2000 Hormone levels and tumour size response to quinagolide and cabergoline in patients with prolactinsecreting and clinically non-functioning pituitary adenomas: predictive value of pituitary scintigraphy with 123I-methoxybenzamide. Clinical Endocrinology (Oxf) 52 437-445. (https://doi.org/10.1046/j.1365-2265.2000.00951.x)

Colao A, Auriemma RS, Lombardi G \& Pivonello R 2011 Resistance to somatostatin analogs in acromegaly. Endocrine Reviews 32 247-271. (https://doi.org/10.1210/er.2010-0002)

Collazo J, Zhu B, Larkin S, Martin SK, Pu H, Horbinski C, Koochekpour S \& Kyprianou N 2014 Cofilin drives cell-invasive and metastatic responses to TGF- $\beta$ in prostate cancer. Cancer Research $\mathbf{7 4} 2362-2373$. (https://doi.org/10.1158/0008-5472.CAN-13-3058)

Cuevas-Ramos D \& Fleseriu M 2014 Somatostatin receptor ligands and resistance to treatment in pituitary adenomas. Journal of Molecular Endocrinology 52 R223-R240. (https://doi.org/10.1530/ JME-14-0011)

Cukier IH, Li Y \& Lee JM 2007 Cyclin B1/Cdk1 binds and phosphorylates Filamin A and regulates its ability to cross-link actin. FEBS Letters 581 1661-1672. (https://doi.org/10.1016/j. febslet.2007.03.041)

Daly AF, Tichomirowa MA, Petrossians P, Heliövaara E, Jaffrain-Rea ML, Barlier A, Naves LA, Ebeling T, Karhu A, Raappana A, et al. 2010 Clinical characteristics and therapeutic responses in patients with germ-line AIP mutations and pituitary adenomas: an international collaborative study. Journal of Clinical Endocrinology and Metabolism 95 E373-E383. (https://doi.org/10.1210/jc.2009-2556) (c) 2019 Society for Endocrinology Published by Bioscientifica Ltd. Printed in Great Britain 
Delgado-López PD, Pi-Barrio J, Dueñas-Polo MT, Pascual-Llorente M \& Gordón-Bolaños MC 2018 Recurrent non-functioning pituitary adenomas: a review on the new pathological classification, management guidelines and treatment options. Clinical and Translational Oncology 20 1233-1245. (https://doi.org/10.1007/ s12094-018-1868-6)

Deyts C, Galan-Rodriguez B, Martin E, Bouveyron N, Roze E, Charvin D, Caboche J \& Bétuing S 2009 Dopamine D2 receptor stimulation potentiates PolyQ-Huntingtin-induced mouse striatal neuron dysfunctions via Rho/ROCK-II activation. PLOS ONE 4 e8287. (https://doi.org/10.1371/journal.pone.0008287)

Feng Y \& Walsh CA 2004 The many faces of filamin: a versatile molecular scaffold for cell motility and signalling. Nature Cell Biology 6 1034-1038. (https://doi.org/10.1038/ncb1104-1034)

Florio T, Barbieri F, Spaziante R, Zona G, Hofland LJ, van Koetsveld PM, Feelders RA, Stalla GK, Theodoropoulou M, Culler MD, et al. 2008 Efficacy of a dopamine-somatostatin chimeric molecule, BIM-23A760, in the control of cell growth from primary cultures of human non-functioning pituitary adenomas: a multi-center study. Endocrine-Related Cancer 15 583-596. (https://doi.org/10.1677/ ERC-07-0271)

Fougner SL1, Bollerslev J, Latif F, Hald JK, Lund T, Ramm-Pettersen J \& Berg JP 2008 Low levels of raf kinase inhibitory protein in growth hormone-secreting pituitary adenomas correlate with poor response to octreotide treatment. Journal of Clinical Endocrinology and Metabolism 93 1211-1216. (https://doi.org/10.1210/jc.2007-2272)

Fox JW, Lamperti ED, Ekşioğlu YZ, Hong SE, Feng Y, Graham DA, Scheffer IE, Dobyns WB, Hirsch BA, Radtke RA, et al. 1998 Mutations in filamin 1 prevent migration of cerebral cortical neurons in human periventricular heterotopia. Neuron 21 1315-1325. (https://doi. org/10.1016/S0896-6273(00)80651-0)

Gadelha MR, Wildemberg LE, Bronstein MD, Gatto F \& Ferone D 2017 Somatostatin receptor ligands in the treatment of acromegaly. Pituitary 20 100-108 (https://doi.org/10.1007/s11102-017-0791-0)

Gagliano T, Filieri C, Minoia M, Buratto M, Tagliati F, Ambrosio MR, Lapparelli M, Zoli M, Frank G, degli Uberti E, et al. 2013 Cabergoline reduces cell viability in non functioning pituitary adenomas by inhibiting vascular endothelial growth factor secretion. Pituitary 16 91-100. (https://doi.org/10.1007/s11102-012-0380-1)

Galan-Rodriguez B, Martin E, Brouillet E, Déglon N, Betuing S \& Caboche J 2017 Coupling of D2R short but not D2R long receptor isoform to the Rho/ROCK signaling pathway renders striatal neurons vulnerable to mutant huntingtin. European Journal of Neuroscience $\mathbf{4 5}$ 198-206. (https://doi.org/10.1111/ejn.13415)

García E, Stracher A \& Jay D 2006 Calcineurin dephosphorylates the C-terminal region of filamin in an important regulatory site: a possible mechanism for filamin mobilization and cell signaling. Archives of Biochemistry and Biophysics 446 140-150. (https://doi. org/10.1016/j.abb.2005.12.006)

Gatto F, Feelders R, van der Pas R, Kros JM, Dogan F, van Koetsveld PM, van der Lelij AJ, Neggers SJ, Minuto F, de Herder W, et al. 2013 $\beta$-Arrestin 1 and 2 and $G$ protein-coupled receptor kinase 2 expression in pituitary adenomas: role in the regulation of response to somatostatin analogue treatment in patients with acromegaly. Endocrinology 154 4715-4725. (https://doi.org/10.1210/en.2013-1672)

Guelho D \& Grossman AB 2015 Emerging drugs for Cushing's disease. Expert Opinion on Emerging Drugs 20 463-478. (https://doi.org/10.151 7/14728214.2015.1047762)

Gurniak CB, Perlas E \& Witke W 2005 The actin depolymerizing factor $\mathrm{n}$-cofilin is essential for neural tube morphogenesis and neural crest cell migration. Developmental Biology 278 231-241. (https://doi. org/10.1016/j.ydbio.2004.11.010)

Halliday WC, Asa SL, Kovacs K \& Scheithauer BW 1990 Intermediate filaments in the human pituitary gland: an immunohistochemical study. Canadian Journal of Neurological Sciences 17 131-136. (https:// doi.org/10.1017/S0317167100030328)
Hammer A, Rider L, Oladimeji P, Cook L, Li Q, Mattingly RR \& Diakonova M 2013 Tyrosyl phosphorylated PAK1 regulates breast cancer cell motility in response to prolactin through filamin A. Molecular Endocrinology 27 455-465 (https://doi.org/10.1210/ me.2012-1291)

Han L, Stope MB, de Jesús ML, Oude Weernink PA, Urban M, Wieland T, Rosskopf D, Mizuno K, Jakobs KH \& Schmidt M 2007 Direct stimulation of receptor-controlled phospholipase D1 by phosphocofilin. EMBO Journal 26 4189-4202. (https://doi.org/10.1038/sj. emboj.7601852)

Hart AW, Morgan JE, Schneider J, West K, McKie L, Bhattacharya S, Jackson IJ \& Cross SH 2006 Cardiac malformations and midline skeletal defects in mice lacking filamin A. Human Molecular Genetics 15 2457-2467. (https://doi.org/10.1093/hmg/ddl168)

Hartwig JH \& Stossel TP 1975 Isolation and properties of actin, myosin, and a new actin binding protein in rabbit alveolar macrophages. Journal of Biological Chemistry 250 5696-5705.

Howell SL \& Tyhurst M 1978 Role of microtubules in the intracellular transport of growth hormone. Cell Tissue Research 190 163-171. (https://doi.org/10.1007/BF00210045)

Ibáñez-Costa A \& Korbonits M 2017 AIP and the somatostatin system in pituitary tumours. Journal of Endocrinology 235 R101-R116.

Ieda D, Hori I, Nakamura Y, Ohshita H, Negishi Y, Shinohara T, Hattori A, Kato T, Inukai S, Kitamura K, et al. 2018 A novel truncating mutation in FLNA causes periventricular nodular heterotopia, Ehlers-Danlos-like collagenopathy and macrothrombocytopenia. Brain and Development 40 489-492. (https://doi.org/10.1016/j.braindev.2018.01.010)

Ithychanda SS, Hsu D, Li H, Yan L, Liu DD, Das M, Plow EF \& Qin J 2009 Identification and characterization of multiple similar ligand binding repeats in filamin: implication on filamin-mediated receptor clustering and crosstalk. Journal of Biological Chemistry $\mathbf{2 8 4}$ 35113-35121. (https://doi.org/10.1074/jbc.M109.060954)

Jay D \& Stracher A 1994 Expression in Escherichia coli and phosphorylation with cAMP-dependent protein kinase of the $\mathrm{N}$-terminal region of human endothelial actin-binding protein. Biochemical and Biophysical Research Communications 202 764-771. (https://doi.org/10.1006/bbrc.1994.1996)

Jay D \& Stracher A 1997 Expression in Escherichia coli, phosphorylation with cAMP-dependent protein kinase and proteolysis by calpain of a 71-kDa domain of human endothelial actin binding protein. Biochemical and Biophysical Research Communications 232 555-558. (https://doi.org/10.1006/bbrc.1997.6238)

Jay D, García EJ, Lara JE, Medina MA \& de la Luz Ibarra M 2000 Determination of a cAMP-dependent protein kinase phosphorylation site in the C-terminal region of human endothelial actin-binding protein. Archives of Biochemistry and Biophysics 377 80-84. (https:// doi.org/10.1006/abbi.2000.1762)

Jay D, García EJ \& de la Luz Ibarra M 2004 In situ determination of a PKA phosphorylation site in the C-terminal region of filamin. Molecular and Cellular Biochemistry 260 49-53. (https://doi. org/10.1023/B:MCBI.0000026052.76418.55)

Kiema T, Lad Y, Jiang P, Oxley CL, Baldassarre M, Wegener KL, Campbell ID, Ylänne J \& Calderwood DA 2006 The molecular basis of filamin binding to integrins and competition with talin. Molecular Cell 21 337-347. (https://doi.org/10.1016/j.molcel.2006.01.011)

Kim KM, Valenzano KJ, Robinson SR, Yao WD, Barak LS \& Caron MG 2001 Differential regulation of the dopamine D2 and D3 receptors by G protein-coupled receptor kinases and beta-arrestins. Journal of Biological Chemistry 276 37409-37414. (https://doi.org/10.1074/jbc.M106728200)

Kiseljak-Vassiliades K, Xu M, Mills TS, Smith EE, Silveira LJ, Lillehei KO, Kerr JM, Kleinschmidt-DeMasters BK \& Wierman ME 2015 Differential somatostatin receptor (SSTR) 1-5 expression and downstream effectors in histologic subtypes of growth hormone pituitary tumors. Molecular and Cellular Endocrinology 417 73-83. (https://doi.org/10.1016/j.mce.2015.09.016) 
Labrie F, Gauthier M, Pelletier G, Borgeat P, Lemay A \& Gouge JJ 1973 Role of microtubules in basal and stimulated release of growth hormone and prolactin in rat adenohypophysis in vitro. Endocrinology 93 903-914. (https://doi.org/10.1210/endo-93-4-903)

Li M, Bermak JC, Wang ZW \& Zhou QY 2000 Modulation of dopamine $\mathrm{D}(2)$ receptor signaling by actin-binding protein (ABP-280). Molecular Pharmacology 57 446-452. (https://doi.org/10.1124/ mol.57.3.446)

Li L, Lu Y, Stemmer PM \& Chen F 2015 Filamin A phosphorylation by Akt promotes cell migration in response to arsenic. Oncotarget 6 12009-12019. (https://doi.org/10.18632/oncotarget.3617)

Lin R, Karpa K, Kabbani N, Goldman-Rakic P \& Levenson R 2001 Dopamine D2 and D3 receptors are linked to the actin cytoskeleton via interaction with filamin A. PNAS 98 5258-5263. (https://doi. org/10.1073/pnas.011538198)

Lin R, Canfield V \& Levenson R 2002 Dominant negative mutants of filamin A block cell surface expression of the D2 dopamine receptor. Pharmacology 66 173-181. (https://doi.org/10.1159/000065531)

Liu C, Gao H, Cao L, Gui S, Liu Q, Li C, Li D, Gong L \& Zhang Y 2016 The role of FSCN1 in migration and invasion of pituitary adenomas Molecular and Cellular Endocrinology 419 217-224. (https://doi. org/10.1016/j.mce.2015.10.021)

Lloyd RV, Osamura RY, Klöppel G, Rosai J (eds) 2017 WHO Classification of Tumours of Endocrine Organs, 4th ed. Lyon: IARC Press.

Losa M, Mortini P, Barzaghi R, Ribotto P, Terreni MR, Marzoli SB, Pieralli S \& Giovanelli M 2008 Early results of surgery in patients with nonfunctioning pituitary tumor and analysis of the risk of tumor recurrence. Journal of Neurosurgery 108 525-532. (https://doi. org/10.3171/JNS/2008/108/3/0525)

Ma X, Zhao Y, Daaka Y \& Nie Z 2012 Acute activation of $\beta 2$-adrenergic receptor regulates focal adhesions through $\beta$ Arrestin2- and p115RhoGEF protein-mediated activation of RhoA. Journal of Biological Chemistry 287 18925-18936. (https://doi.org/10.1074/jbc. M112.352260)

Marazuela M, Ramos-Leví AM, Borges de Souza P \& Zatelli MC 2018 Is receptor profiling useful for predicting pituitary therapy? European Journal of Endocrinology 179 D15-D25. (https://doi.org/10.1530/EJE18-0549)

Meiji BP, Lopes MS, Ellegala DB, Alden T \& Laws ER Jr 2002 The longterm significance of microscopic dural invasion in 354 patients with pituitary tumors treated with transsphenoidal surgery. Journal of Neurosurgery 96 195-208. (https://doi.org/10.3171/ jns.2002.96.2.0195)

Nagai S, Moreno O, Smith CA, Ivanchuk S, Romagnuolo R, Golbourn B, Weeks A, Seol HJ \& Rutka JT 2011 Role of the cofilin activity cycle in astrocytoma migration and invasion. Genes and Cancer 2 859-869. (https://doi.org/10.1177/1947601911431839)

Najib S, Saint-Laurent N, Estève JP, Schulz S, Boutet-Robinet E, Fourmy D, Lättig J, Mollereau C, Pyronnet S, Susini C, et al. 2012 A switch of $\mathrm{G}$ protein-coupled receptor binding preference from phosphoinositide 3-kinase (PI3K)-p85 to filamin A negatively controls the PI3K pathway. Molecular and Cellular Biology 32 1004-1016. (https://doi.org/10.1128/MCB.06252-11)

Nakamura F, Stossel TP \& Hartwig JH 2011 The filamins: organizers of cell structure and function. Cell Adhesion and Migration 5 160-169.

Oegema R, Hulst JM, Theuns-Valks SD, van Unen LM, Schot R, Mancini GM, Schipper ME, de Wit MC, Sibbles BJ, de Coo IF, et al. 2013 Novel no-stop FLNA mutation causes multi-organ involvement in males. American Journal of Medical Genetics Part A $\mathbf{1 6 1 A}$ 2376-2384. (https://doi.org/10.1002/ajmg.a.36109)

Ostlund RE, Leung JT \& Kipnis DM 1977 Muscle actin filaments bind pituitary secretory granules in vitro. Journal of Cell Biology 73 78-87. (https://doi.org/10.1083/jcb.73.1.78)

Ostrom QT, Gittleman H, Liao P, Vecchione-Koval T, Wolinsky Y, Kruchko C \& Barnholtz-Sloan JS 2017 CBTRUS statistical report: primary brain and other central nervous system tumors diagnosed in the United States in 2010-2014. Neuro-Oncology 19 (Supplement 5) v1-v88. (https://doi.org/10.1093/neuonc/nox158)

Paragliola RM, Corsello SM \& Salvatori R 2017 Somatostatin receptor ligands in acromegaly: clinical response and factors predicting resistance. Pituitary 20 109-115. (https://doi.org/10.1007/s11102016-0768-4)

Pendleton A, Pope B, Weeds A \& Koffer A 2003 Latrunculin B or ATP depletion induces cofilin-dependent translocation of actin into nuclei of mast cells. Journal of Biological Chemistry 278 14394-14400. (https://doi.org/10.1074/jbc.M206393200)

Pentikäinen U, Jiang P, Takala H, Ruskamo S, Campbell ID \& Ylänne J 2011 Assembly of a filamin four-domain fragment and the influence of splicing variant-1 on the structure. Journal of Biological Chemistry 286 26921-26930. (https://doi.org/10.1074/jbc.M110.195958)

Percipalle P 2013 Co-transcriptional nuclear actin dynamics. Nucleus 4 43-52. (https://doi.org/10.4161/nucl.22798)

Peverelli E, Mantovani G, Calebiro D, Doni A, Bondioni S, Lania A, Beck-Peccoz P \& Spada A 2008 The third intracellular loop of the human somatostatin receptor 5 is crucial for arrestin binding and receptor internalization after somatostatin stimulation. Molecular Endocrinology 22 676-688. (https://doi.org/10.1210/me.2007-0068)

Peverelli E, Olgiati L, Locatelli M, Magni P, Fustini MF, Frank G, Mantovani G, Beck-Peccoz P, Spada A \& Lania A 2010 The dopamine-somatostatin chimeric compound BIM-23A760 exerts antiproliferative and cytotoxic effects in human non-functioning pituitary tumors by activating ERK1/2 and p38 pathways. Cancer Letters 288 170-176. (https://doi.org/10.1016/j.canlet.2009.06.034)

Peverelli E, Mantovani G, Vitali E, Elli FM, Olgiati L, Ferrero S, Laws ER, Della Mina P, Villa A, Beck-Peccoz P, et al. 2012 Filamin-A is essential for dopamine D2 receptor expression and signaling in tumorous lactotrophs. Journal of Clinical Endocrinology and Metabolism 97 967-977. (https://doi.org/10.1210/jc.2011-2902)

Peverelli E, Giardino E, Treppiedi D, Vitali E, Cambiaghi V, Locatelli M, Lasio GB, Spada A, Lania AG \& Mantovani G 2014 Filamin A (FLNA) plays an essential role in somatostatin receptor 2 (SSTR2) signaling and stabilization after agonist stimulation in human and rat somatotroph tumor cells. Endocrinology 155 2932-2941. (https://doi. org/10.1210/en.2014-1063)

Peverelli E, Treppiedi D, Giardino E, Vitali E, Lania AG \& Mantovani G 2015 Dopamine and somatostatin analogues resistance of pituitary tumors: focus on cytoskeleton involvement. Frontiers in Endocrinology 6 187. (https://doi.org/10.3389/fendo.2015.00187)

Peverelli E, Giardino E, Treppiedi D, Locatelli M, Vaira V, Ferrero S, Bosari S, Lania AG, Spada A \& Mantovani G 2016 Dopamine receptor type 2 (DRD2) inhibits migration and invasion of human tumorous pituitary cells through ROCK-mediated cofilin inactivation. Cancer Letters 381 279-286. (https://doi.org/10.1016/j. canlet.2016.08.005)

Peverelli E, Giardino E, Treppiedi D, Catalano R, Mangili F, Locatelli M, Lania A, Arosio M, Spada A \& Mantovani G 2018a A novel pathway activated by somatostatin receptor type 2 (SSTR2): inhibition of pituitary tumor cell migration and invasion through cytoskeleton protein recruitment. International Journal of Cancer 142 1842-1852. (https://doi.org/10.1002/ijc.31205)

Peverelli E, Giardino E, Mangili F, Treppiedi D, Catalano R, Ferrante E, Sala E, Locatelli M, Lania AG, Arosio M, et al. 2018b cAMP/PKAinduced filamin A (FLNA) phosphorylation inhibits SST2 signal transduction in GH-secreting pituitary tumor cells. Cancer Letters 435 101-109. (https://doi.org/10.1016/j.canlet.2018.08.002)

Pons M, Izquierdo I, Andreu-Carbó M, Garrido G, Planagumà J, Muriel O, Del Pozo MA, Geli MI \& Aragay AM 2017 Phosphorylation of filamin A regulates chemokine receptor CCR2 recycling. Journal of Cell Science 130 490-501. (https://doi.org/10.1242/jcs.193821)

Popow-Woźniak A, Mazur AJ, Mannherz HG, Malicka-Błaszkiewicz M \& Nowak D 2012 Cofilin overexpression affects actin cytoskeleton organization and migration of human colon adenocarcinoma cells. https://erc.bioscientifica.com

https://doi.org/10.1530/ERC-18-0442 (c) 2019 Society for Endocrinology Published by Bioscientifica Ltd. Printed in Great Britain 
Histochemistry and Cell Biology 138 725-736. (https://doi. org/10.1007/s00418-012-0988-2)

Ravid D, Chuderland D, Landsman L, Lavie Y, Reich R \& Liscovitch M 2008 Filamin A is a novel caveolin-1-dependent target in IGF-Istimulated cancer cell migration. Experimental Cell Research 314 2762-2773. (https://doi.org/10.1016/j.yexcr.2008.06.004)

Razinia Z, Baldassarre M, Bouaouina M, Lamsoul I, Lutz PG \& Calderwood DA 2011 The E3 ubiquitin ligase specificity subunit ASB2 $\alpha$ targets filamins for proteasomal degradation by interacting with the filamin actin-binding domain. Journal of Cell Science $\mathbf{1 2 4}$ 2631-2641. (https://doi.org/10.1242/jcs.084343)

Reincke M, Sbiera S, Hayakawa A, Theodoropoulou M, Osswald A, Beuschlein F, Meitinger T, Mizuno-Yamasaki E, Kawaguchi K, Saeki Y, et al. 2015 Mutations in the deubiquitinase gene USP8 cause Cushing's disease. Nature Genetics 47:31-38. (https://doi.org/ 10.1038/ng.3166)

Robertson SP 2005 Filamin A: phenotypic diversity. Current Opinion in Genetics and Development 15 301-307. (https://doi.org/10.1016/j. gde.2005.04.001)

Robertson SP, Twigg SR, Sutherland-Smith AJ, Biancalana V, Gorlin RJ, Horn D, Kenwrick SJ, Kim CA, Morava E, Newbury-Ecob R, et al. 2003 Localized mutations in the gene encoding the cytoskeletal protein filamin A cause diverse malformations in humans. Nature Genetics 33 487-491. (https://doi.org/10.1038/ng1119)

Sarkar S, Rajaratnam S, Chacko G \& Chacko AG 2014 Endocrinological outcomes following endoscopic and microscopic transsphenoidal surgery in 113 patients with acromegaly. Clinical Neurology and Neurosurgery 126 190-195. (https://doi.org/10.1016/j. clineuro.2014.09.004)

Sato T, Ishii J, Ota Y, Sasaki E, Shibagaki Y \& Hattori S 2016 Mammalian target of rapamycin (mTOR) complex 2 regulates filamin A-dependent focal adhesion dynamics and cell migration. Genes to Cells 21 579-593. (https://doi.org/10.1111/gtc.12366)

Seck T, Baron R \& Horne WC 2003 Binding of filamin to the C-terminal tail of the calcitonin receptor controls recycling. Journal of Biological Chemistry 278 10408-10416. (https://doi.org/10.1074/jbc. M209655200)

Senda T, Fujita H, Ban T, Zhong C, Ishimura K, Kanda K \& Sobue K 1989 Ultrastructural and immunocytochemical studies on the cytoskeleton in the anterior pituitary of rats, with special regard to the relationship between actin filaments and secretory granules. Cell and Tissue Research 258 25-30.

Shao QQ, Zhang TP, Zhao WJ, Liu ZW, You L, Zhou L, Guo JC \& Zhao YP 2016 Filamin A: insights into its exact role in cancers. Pathology and Oncology Research 22 245-252. (https://doi. org/10.1007/s12253-015-9980-1)

Sheen VL, Jansen A, Chen MH, Parrini E, Morgan T, Ravenscroft R, Ganesh V, Underwood T, Wiley J, Leventer R, et al. 2005 Filamin A mutations cause periventricular heterotopia with Ehlers-Danlos syndrome. Neurology 64 254-262. (https://doi.org/10.1212/01. WNL.0000149512.79621.DF)

Sherline P, Lee YC \& Jacobs LS 1977 Binding of microtubules to pituitary secretory granules and secretory granule membranes. Journal of Cell Biology 72 380-389. (https://doi.org/10.1083/ jcb.72.2.380)

Shishkin S, Eremina L, Pashintseva N, Kovalev L \& Kovaleva M 2016 Cofilin-1 and other ADF/cofilin superfamily members in human malignant cells. International Journal of Molecular Sciences $\mathbf{1 8}$ E10 (https://doi.org/10.3390/ijms18010010)

Song X, Chen X, Yamaguchi H, Mouneimne G, Condeelis JS \& Eddy RJ 2006 Initiation of cofilin activity in response to EGF is uncoupled from cofilin phosphorylation and dephosphorylation in carcinoma cells. Journal of Cell Science 119 2871-2881 (https://doi.org/10.1242/ jcs.03017)

Stossel TP, Condeelis J, Cooley L, Hartwig JH, Noegel A, Schleicher M \& Shapiro SS 2001 Filamins as integrators of cell mechanics and signalling. Nature Reviews: Molecular Cell Biology 2 138-145. (https:// doi.org/10.1038/35052082)

Thelin WR, Chen Y, Gentzsch M, Kreda SM, Sallee JL, Scarlett CO, Borchers CH, Jacobson K, Stutts MJ \& Milgram SL 2007 Direct interaction with filamins modulates the stability and plasma membrane expression of CFTR. Journal of Clinical Investigation 117 364-374. (https://doi.org/10.1172/JCI30376)

Tirosh A \& Shimon I 2015 Management of macroprolactinomas. Clinical Diabetes and Endocrinology 15 (https://doi.org/10.1186/ s40842-015-0006-4)

Treppiedi D, Jobin ML, Peverelli E, Giardino E, Sungkaworn T, Zabel U, Arosio M, Spada A, Mantovani G \& Calebiro D 2018 Single-molecule microscopy reveals dynamic FLNA interactions governing SSTR2 clustering and internalization. Endocrinology 159 2953-2965. (https://doi.org/10.1210/en.2018-00368)

Tulipano G, Stumm R, Pfeiffer M, Kreienkamp HJ, Höllt V \& Schulz S 2004 Differential beta-arrestin trafficking and endosomal sorting of somatostatin receptor subtypes. Journal of Biological Chemistry 279 21374-21382. (https://doi.org/10.1074/jbc.M313522200)

van der Flier A \& Sonnenberg A 2001 Structural and functional aspects of filamins. Biochimica et Biophysica Acta 1538 99-117. (https://doi. org/10.1016/S0167-4889(01)00072-6)

van der Flier A, Kuikman I, Kramer D, Geerts D, Kreft M, Takafuta T, Shapiro SS \& Sonnenberg A 2002 Different splice variants of filamin-B affect myogenesis, subcellular distribution, and determine binding to integrin (beta) subunits. Journal of Cell Biology $\mathbf{1 5 6}$ 361-376. (https://doi.org/10.1083/jcb.200103037)

Vieira Neto L, Wildemberg LE, Moraes AB, Colli LM, Kasuki L, Marques NV, Gasparetto EL, de Castro M, Takiya CM \& Gadelha MR 2015 Dopamine receptor subtype 2 expression profile in nonfunctioning pituitary tumors and in vivo response to cabergoline therapy. Clinical Endocrinology 82 739-746. (https://doi.org/10.1111/ cen.12684)

Vitali E, Cambiaghi V, Zerbi A, Carnaghi C, Colombo P, Peverelli E, Spada A, Mantovani G \& Lania AG 2016 Filamin-A is required to mediate SST2 effects in pancreatic neuroendocrine tumours. Endocrine Related Cancer 23 181-190. (https://doi.org/10.1530/ ERC-15-0358)

Wang W, Mouneimne G, Sidani M, Wyckoff J, Chen X, Makris A, Goswami S, Bresnick AR \& Condeelis JS 2006 The activity status of cofilin is directly related to invasion, intravasation, and metastasis of mammary tumors. Journal of Cell Biology 173 395-404. (https://doi. org/10.1083/jcb.200510115)

Wang Y, Kuramitsu Y, Kitagawa T, Baron B, Yoshino S, Maehara S, Oka M \& Nakamura K 2015 Cofilin-phosphatase slingshot-1L (SSH1L) is over-expressed in pancreatic cancer (PC) and contributes to tumor cell migration. Cancer Letters 360 171-176. (https://doi. org/10.1016/j.canlet.2015.02.015)

Woo MS, Ohta Y, Rabinovitz I, Stossel TP \& Blenis J 2004 Ribosomal S6 kinase (RSK) regulates phosphorylation of filamin A on an important regulatory site. Molecular Cell Biology 24 3025-3035. (https://doi. org/10.1128/MCB.24.7.3025-3035.2004)

Wu MP, Jay D \& Stracher A 1994 Existence of multiple phosphorylated forms of human platelet actin binding protein. Cellular and Molecular Biology Research 40 351-357.

Wu ZB, Zheng WM, Su ZP, Chen Y, Wu JS, Wang CD, Lin C, Zeng YJ \& Zhuge QC 2010 Expression of D2RmRNA isoforms and ERmRNA isoforms in prolactinomas: correlation with the response to bromocriptine and with tumor biological behavior. Journal of Neuro-Oncology 99 25-32. (https://doi.org/10.1007/ s11060-009-0107-y)

Yang ZL, Miao X, Xiong L, Zou Q, Yuan Y, Li J, Liang L, Chen M \& Chen S 2013 CFL1 and Arp3 are biomarkers for metastasis and poor prognosis of squamous cell/adenosquamous carcinomas and adenocarcinomas of gallbladder. Cancer Investigation 31 132-139. (https://doi.org/10.3109/07357907.2012.756113) 
Communications 151 355-360 (https://doi.org/10.1016/0006291X(88)90601-8)

Zhang M \& Breitwieser GE 2005 High affinity interaction with filamin A protects against calcium-sensing receptor degradation. Journal of Biological Chemistry 280 11140-11146. (https://doi.org/10.1074/jbc. M412242200)

Zhang Y \& Tong X 2010 Expression of the actin-binding proteins indicates that cofilin and fascin are related to breast tumour size. Journal of International Medical Research 38 1042-1048. (https://doi. org $/ 10.1177 / 147323001003800331$ )

Zhang Z, Lawrence J \& Stracher A 1988 Phosphorylation of platelet actin binding protein protects against proteolysis by calcium dependent sulfhydryl protease. Biochemical and Biophysical Research hang J, Neal J, Lian G, Shi B, Ferland RJ \& Sheen V 2012 Brefeldin A-inhibited guanine exchange factor 2 regulates filamin A phosphorylation and neuronal migration. Journal of Neuroscience 32 12619-12629. (https://doi.org/10.1523/JNEUROSCI.1063-12.2012)

Zheng M, Zhang X, Sun N, Min C, Zhang X \& Kim KM 2016 RalA employs GRK2 and $\beta$-arrestins for the filamin A-mediated regulation of trafficking and signaling of dopamine D2 and D3 receptor. Biochimica et Biophysica Acta 1863 2072-2083. (https://doi. org/10.1016/j.bbamcr.2016.05.010)

Received in final form 14 November 2018

Accepted 4 December 2018 (c) 2019 Society for Endocrinology Published by Bioscientifica Ltd. Printed in Great Britain 